\title{
ESTIMATION OF TOTAL PHENOLIC, TOTAL FLAVONOID CONTENT AND EVALUATION OF ANTI-INFLAMMATORY AND ANTIOXIDANT ACTIVITY OF IXORA COCCINEA LINN. STEMS
}

\author{
Surana Ajaykumar Rikhabchand ${ }^{1} *$ Wagh Rajendra Dayaram ${ }^{2}$
}

\author{
1.S.M.B.T. College of \\ Pharmacy, Dhamangaon, Tal- \\ Igatpuri, Dist-Nashik, M.S. \\ 422403 \\ 2.A.R.A. College of Pharmacy, \\ Dhule, M.S- 424005
}

Submitted: 05-02-2017

Revised: 20-03-2017

Accepted: 06-04-2017

${ }^{*}$ Corresponding author

Ajay Surana

Email:

ajaysurana01@rediffmail.com

\begin{abstract}
Ixora coccinea Linn. (Rubiaceae) has mentioned in Ayurveda as Paranti and traditionally stems used in inflammatory diseases like sprains, eczema, contusions and boils. Present study deals with evaluation of anti-inflammatory and antioxidant activity of extracts of I.coccinea stem. Antiinflammatory activity was studied in vivo by carrageenaninduced paw edema in rat and in vitro by human red blood cell membrane stabilization method. Total tannin and flavonoid content of extracts was determined by using the Folin- Ciocalteu method and aluminum chloride method, respectively. Antioxidant activity was evaluated by in vitro assay involving nitric oxide scavenging, hydrogen peroxide scavenging, 2,2diphenylpicrylhydrazyl (DPPH) radical scavenging, and ion chelating activity. Chloroform extract showed significant reduction in carrageenan induced rat paw edema $(p<0.05)$ and protection of HRBC in hypotonic solution. Methanol extract contain more total tannin and flavonoid content as compared with petroleum ether and chloroform extract. All extracts showed concentration dependant free radical scavenging activity. Methanol extract and chloroform extract have shown better antioxidant activity and due to this antioxidant nature might be responsible for its anti-inflammatory activity. These activity supports to use of I.coccinea extract in traditional used in treatment of various inflammatory disaeses.
\end{abstract}

Key words: Anti-inflammatory activity; Antioxidant activity; Carrageenan-induced paw edema; HRBC; Ixora coccinea

\section{INTRODUCTION}

Despite the development in medical field during the past years, the treatment of severe diseases is still challenging. Inflammatory diseases remain with others one of the world's major health problems (Martínez-Vázquez et al., 2012). Inflammation or phlogosis is an immunlogical reaction of living tissues to injuries that leads to accumulation of blood fluids and cells. Even though it is an immunological defense, the complex reaction but mediators involved in the inflammation can induces many diseases. Hence, the use of antiinflammatory substances is helpful to treat therapeutically this pathological condition (Sosa et al., 2002). An anti-inflammatory drug like NSAID's used to decrease the swelling and pain of inflammation of tissue. But prolonged use of anti-inflammatory agents may produce gastro-intestinal toxicity, cardiovascular and other toxicity. Therefore, there is a need for anti-inflammatory drugs having less severe side effects to use for chronic inflammatory diseases. Therefore, in recent time, more interest is shown in traditional drugs for treatment of various diseases, but there is no or less scientific evidences (Madhavi et al., 2012).

The oxidative condition presents a range of free radicals including nitric oxide, hydroxyl radical, superoxide and peroxynitrite in living organisms. There are a number of evidences about the role of free radicals in the development of various diseases including cancer, neurodegeneration and inflammatory diseases (Ferguson, 2010; Halliwell, 2006). Antioxidants therefore gained importance for their capacity to reduce these diseases produce from free radicals. In this context, antioxidant properties of various medicinal plants are being investigated throughout the world because of 
the toxicological concerns associated with the synthetic antioxidants (Peschel et al., 2006).

Ixora coccinea Linn. Family-Rubiaceae is medicinal plant widely found in tropical region of East Indies and subtropical region of India and Shrilanka. (Basu et al., 1999). Flowers contain cycloartenol esters (Ragasa et al., 2004) and leaves contain Ixorene dammarane triterpene (Ikram et al., 2013). Leaves show anti-inflammatory (Muke et al., 2013), cardioprotective effect (Momin et al., 2012), antinociceptive (Ratnasooriya et al., 2005), antioxidant (Babu et al., 2014; Saha et al., 2008), antidiarrhoeal (Yasmeen et al., 2010), antiasthmatic (Missebukpo et al., 2011), hypoglycaemic and hypolipidaemic activity (Maniyar and Bhixavatimath, 2011).The roots and flowers shows anthelmintic (Surana et al., 2012) and antioxidant activity (Saha et al., 2008; Surana et al., 2013).

From literature review it reveals that stems of $I$. coccinea has traditionally used in inflammatory conditions like sprains, eczema, contusions and boils (Mhaskar et al., 2000) and no scientific work was done on stems of $I$. coccinea for anti-inflammatory activity and antioxidant activity. This study was designed to assessment of anti-inflammatory, antioxidant potential and total tannin and flavonoid contents of extracts of I. coccinea stems.

\section{MATERIALS AND METHODS Drugs and chemicals}

DPPH used in this study was obtained from Sigma-Aldrich, India, Diclofenac sodium and carrageenan was purchased from TCI Chemical (India) Pvt. Ltd., sulfanilamide and NADH obtained from Hi Media Laboratories Pvt., India. Rutin, Folin-Ciocalteu Reagent ascorbic acid, tocopherol, ferrozine obtained from Qualigens Fine Chemicals and sodium nitroprusside, N-(1-naphthyl)-ethylenediamine hydrochloride, sodium nitrite, ferrous chloride purchased from S.D. Fine Chemicals Ltd., India. Other reagents were purchased locally. All chemicals used in the study were of analytical grade.

\section{Authentication of plant material and Preparation of extract}

The stems of $I$. coccinea were collected from Dhule District. Dr. P. S. N. Rao, Scientist,
Botanical survey of India (BSI), Pune did the identification and authentication of plant. The herbarium of the plant has been deposited at BSI, Pune have voucher specimen Number, ARS-1.

The air-dried stems of $I$. coccinea were pulverized in grinder (\# 60-80) and successively extracted with petroleum ether (60$80^{\circ} \mathrm{C}$ ), chloroform and methanol by Soxhlet apparatus. After completion of extraction, solvent was distilled out and dried the extract in vacuum dryer.

\section{Animals}

The tests with animals (Male Wistar rats weighing 150-200g) experimental were performed according to guidelines for the care and use of laboratory animals of the Committee for the Purpose of Control and Supervision of Experiments on Animals, India (CPCESEA) and approved by the Institutional Animal ethical committee.

\section{Determination of total Tannins}

The extracts of $I$. coccinea were analyzed for its tannins content according to the FolinCiocalteu colorimetric method described by Spanos with slight modifications (Spanos and Wrolstad, 1990). The assay was performed by taking stock solution of each extract $(1 \mathrm{~mL}$, $1 \mathrm{mg} / \mathrm{mL}$ ) and $1 \mathrm{~mL}$ of different dilutions of standard gallic acid (25 to $250 \mu \mathrm{g} / \mathrm{mL}$ ) in volumetric flask $(25 \mathrm{~mL})$. Followed by addition of water $(10 \mathrm{~mL})$ and Folin-Ciocalteu Reagent $(1.5 \mathrm{~mL})$ and allowed to stand for $10 \mathrm{~min}$. Then sodium carbonate solution $(4 \mathrm{~mL})$ was added in each volumetric flask and made volume up to the mark with distilled water. Absorbance was taken after $1 \mathrm{~h}$ at $765 \mathrm{~nm}$ by $\mathrm{UV}$ visible spectrophotometer (Shimatzu) against blank. The calibration curve of gallic acid was plotted and tannin content determined from calibration curve.

\section{Total flavonoid content}

The flavonoids content of I. coccinea was determined according to the Aluminium chloride method performed by Kumaran and Karunakaran (Kumaran and Joel Karunakaran, 2007). Total flavonoid content was analysed by taking $0.5 \mathrm{~mL}$ stock solution of each extract $(1 \mathrm{mg} / \mathrm{mL})$ and different dilution of standard 
rutin solution $(10$ to $100 \mu \mathrm{g} / \mathrm{mL}$ ) in separate test tubes. In each test tube methanol $(1.5 \mathrm{~mL})$, aluminium chloride solution $(0.1 \mathrm{~mL})$, potassium acetate solution (each $0.1 \mathrm{~mL}$ ) and distilled water $(2.8 \mathrm{~mL})$ were added and mixed well. Blank solutions for all the extract and for different dilution of standard rutin were prepared by addition of distilled water in place of aluminium chloride solution. Filtered all prepared solutions were through Whatmann filter paper before determining absorbance. Absorbance was taken at $415 \mathrm{~nm}$ against the suitable blank. The amount of flavonoid in the extract was determined from calibration curve of rutin.

\section{Anti-inflammatory activity In vitro Human Red Blood Cell (HRBC) membrane stabilizing activity}

This method is useful to evaluate membrane Stabilizing activity of HRBC when in inflammation blood capillaries are breaks. The 10\% Human red blood cell suspension prepared in normal saline solution (Khouya et al., 2015).

HRBC Membrane Stabilizing activity was performed according to method described by Kumar et al., 2011. Various dilutions of

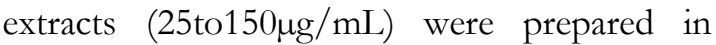
distilled water. In each extract, $1 \mathrm{~mL}$ phosphate buffer $(0.15 \mathrm{M} \mathrm{pH} 7.4), 2 \mathrm{~mL}$ hyposaline and $0.5 \mathrm{~mL}$ HRBC suspension were added. The resultant mixture was incubated at $37^{\circ} \mathrm{C}$ for $30 \mathrm{~min}$. After, it centrifuged at $3000 \mathrm{rpm}$ for $10 \mathrm{~min}$. The hemoglobin content of the supernatant solution was determined by taking absorbance at 560nm using UV-visible spectrophotometer (Shimatzu). Diclofenac sodium (10 to $50 \mu \mathrm{g} / \mathrm{mL}$ ) were used as standard and a control was prepared excluding the test component (Kumar et al., 2011). The \% inhibition of haemolysis or membrane stabilization of HRBC was detrmined by using following formula-

$\%$ inhibition of haemolysis $=\frac{\mathrm{A}_{\text {control- }} \mathrm{A}_{\text {test }}}{\mathrm{A}_{\text {control }}} \times 100$

Where; $\mathrm{A}_{\text {control }}=$ Optical density of control i.e. HRBC in hypotonic-buffered saline solution alone; $\mathrm{A}_{\text {test }}=$ Optical density of test component in HRBC in hypotonic-buffered saline solution

\section{In Vivo Carrageenan-induced paw edema}

The Wister albino rats were divided into 5 groups, each group consists of 6 animals. The edema was produced by injection of $0.1 \mathrm{~mL}$ of carrageenan $(1 \% \mathrm{w} / \mathrm{v}$ suspension in normal saline solution) locally into subplantar region of the left hind paw of rats. Extracts of $I$. coccinea (100mg/kg body weight) and diclofenac (10mg/kg, body weight) were given orally $1 \mathrm{~h}$ prior of carrageenan injection. Control group only received vehicle. The paw volume of rat up to the ankle joint was measured at $0 \mathrm{~h}, 1 \mathrm{~h}, 2 \mathrm{~h}$ and $3 \mathrm{~h}$ by using Plethysmometer PLM01(Ferreira et al., 2013; Nagulsamy et al., 2015).

\section{Antioxidant activity}

Nitric Oxide Radical Scavenging Assay

Nitric oxide (NO) scavenging activity of $I$. coccinea extracts was performed by sodium Nitroprusside-Griess reagent method (Gülçin et al., 2012; Kumbhare et al., 2012).

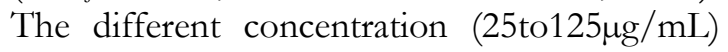
of $I$. coccinea extracts in methanol were mixed with $1 \mathrm{mM}$ sodium nitroprusside solution in phosphate buffer saline solution and incubated at $37^{\circ} \mathrm{C}$ for $2.5 \mathrm{~h}$. Blank solution was also prepared excluding test component. After incubation, and $0.5 \mathrm{~mL}$ of Griess reagent (1\% sulphanilamide, 2\% o-phosphoric acid and $\quad 0.1 \% \quad \mathrm{~N}$-(1-naphthyl)-ethylenediamine hydrochloride) and absorbance was taken at $546 \mathrm{~nm}$ immediately. Ascorbic acid was used as standard. Percent inhibition was calculated as per following formula. $\mathrm{IC}_{50}$ was calculated for each extract.

$\%$ inhibition $=\quad \frac{\mathrm{A}_{\text {control }}-\mathrm{A}_{\text {test }}}{\mathrm{A}_{\text {control }}} \times 100$

\section{Hydrogen peroxide scavenging activity}

The hydrogen peroxide scavenging activity was measured by the method described earlier. (Amzad Hossain and Shah, 2015; Xiao et al., 2012). A hydrogen peroxide solution $(40 \mathrm{mM})$ was prepared in phosphate buffer $\mathrm{pH}$ 7.4. Different dilution $(25 \mathrm{to} 125 \mu \mathrm{g} / \mathrm{mL})$ of $I$. coccinea extracts was prepared in methanol. In that hydrogen peroxide solution $(0.6 \mathrm{~mL})$ was added. The absorbance of hydrogen peroxide was determined after $10 \mathrm{~min}$. at $230 \mathrm{~nm}$. Percent inhibition calculated as per above formula \& $\mathrm{IC}_{50}$ calculated 


\section{DPPH Free radical scavenging assay}

DPPH Free Radical Scavenging inhibiting Activity was performed as described by Nwaehujor et al., 2014. Various concentrations of each $I$. coccinea extract were prepared in methanol. In each different dilution $(25 \mathrm{to} 125 \mu \mathrm{g} / \mathrm{mL})$ of extract solution $(4 \mathrm{~mL})$, $100 \mu \mathrm{L}$ of $\mathrm{DPPH}$ solution $(13 \mathrm{mg} / \mathrm{Lit}$ ) was added. $100 \mu$ l of DPPH solution in methanol (4 $\mathrm{mL}$ ) was treated as control. Ascorbic acid was used as standard. Absorbance of each solution was taken after $15 \mathrm{~min}$. at $517 \mathrm{~nm}$. Percent inhibition calculated as per above formula \& $\mathrm{IC}_{50}$ calculated.

\section{Ferrous chelating activity}

The chelating activity of the $I$. coccinea extracts toward ferrous ions was studied by the previously describe method (Dinis et al., 1994). In $1 \mathrm{~mL}$ of each dilution $(25 \mathrm{to} 125 \mu \mathrm{g} / \mathrm{mL}$ ) of $I$. coccinea extracts, $2 \mathrm{mM} \mathrm{FeCl}_{2}(0.1 \mathrm{~mL})$ was added and the chelating reaction was started by the addition of $5 \mathrm{mM}$ ferrozine $(0.2 \mathrm{~mL})$ and the reaction mixture was vigorously shaken for $10 \mathrm{~s}$ and stand for $10 \mathrm{~min}$. at room temperature and the absorbance was determined at $562 \mathrm{~nm}$. Reaction mixture without test sample was used as a control and without ferrozine mixture was used as a blank.

\section{Statistical analysis}

All animal experimental results are given as the mean \pm standard error of the mean (SEM).To compare experimental and control groups, we used two-way analysis of variance (ANOVA), followed by by Bonferroni's test. A value of $\mathrm{P}<0.05$ was considered to be significant. All in vitro experimental results are given as the mean \pm standard deviation (SD)

\section{RESULT AND DISCUSSION \\ Determination of total phenolics}

The Folin-Ciocalteu method is responsive to reducing compounds like polyphenols and tannins there by forming blue colored complex. Table I shows the total tannin content of the $I$. coccinea extracts measured using the Folin-Ciocalteu method. The linear regression equations and linear regression coefficient of calibration curve was $y=0.004 x$ and $R^{2}=0.992$ respectively, where $x$ is the absorbance and $y$ is the concentration of gallic acid solution $(\mu \mathrm{g} / \mathrm{mL})$. The total tannin content of the extracts were $19.17 \pm 1.01,34.25 \pm 1.28$ and $121.75 \pm 1.14 \mathrm{mg} \mathrm{GAE} / \mathrm{g}$ for petroleum ether, chloroform and methanol extract respectively (Table I).

Table I. Total phenolics and flavonoid content of $I$. coccinea stems extracts

\begin{tabular}{ccc}
\hline Sample & Total phenolics & Total flavonoid \\
\hline PIC & $19.17 \pm 1.01$ & $6.76 \pm 0.64$ \\
CIC & $34.25 \pm 1.28$ & $17.38 \pm 1.36$ \\
MIC & $121.75 \pm 1.14$ & $38.71 \pm 0.85$ \\
\hline
\end{tabular}

Values represent mean \pm standard deviation $(n=3)$

Plant tannin components are secondary metabolites with beneficial role in animals as well as human health. The valuable effects of those tannins are due to their antioxidant activity involving their capability to scavenge free radicals, accept hydrogen atoms, donate electrons or to chelate metal ions (Kasote et al., 2015). Tannin contents of all the $I$. coccinea extracts may appear to function as good antioxidant.

\section{Determination of total flavonoid}

The total flavonoid content of the $I$. coccinea extract was determined using the aluminium chloride colorimetric method. The total flavonoid content values were obtained from the calibration curve. The linear regression equations and linear regression coefficient of calibration curve was $y=0.007 x$ $\mathrm{R}^{2}=0.996$ respectively, where $x$ is the absorbance and $y$ is the concentration of rutin solution $(\mu \mathrm{g} / \mathrm{mL})$ expressed as $\mathrm{mg}$ of rutin equivalent $/ g$ of extract. Results of total flavonoids content of $I$. coccinea extracts (Table I).

\section{Anti-inflammatory activity In vitro human red blood cell membrane stabilizing activity}

HRBC membrane is similar to lysosomal membrane. In inflammatory process histamine released from injured tissue causes blood capillaries more permeable and damaged tissue releases their enzymes, which break down the damaged tissue but may also destruct nearly 
healthy tissue cells (Nagaharika et al., 2013). I. coccinea extracts stabilizes HRBC and may stabilizes lysosomes in injured tissue cells and thereby prevent release of lysosomal enzymes into cells, thus preventing deterioration of tissue. Petroleum ether, chloroform, methanol extracts of $I$. coccinea and diclofenac sodium showed HRBC membrane stabilizing activity, stabilizing HRBC membrane upto $21.207 \%$, $30.865 \%, 26.686 \%$ and $35.173 \%$ respectively at conc. $250 \mu \mathrm{g} / \mathrm{mL}$ in hypotonic solution (Figure 1). By comparing HRBC membrane stabilizing activity of all the extracts it was found that chloroform extract has better in vitro antiinflammatory activity.

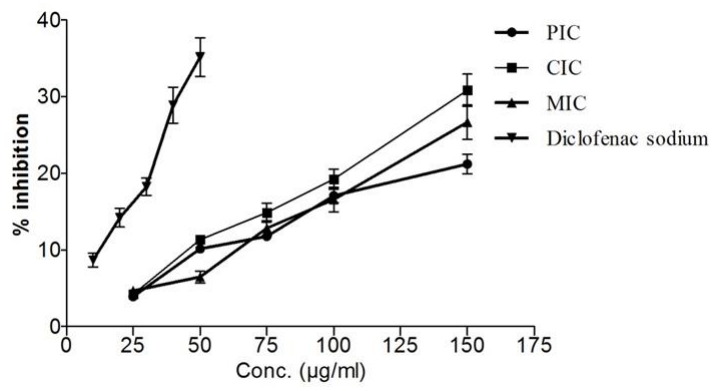

Figure 1. In vitro HRBC Membrane Stabilizing activity of extracts of Ixora cocinea stems. Each value represents mean $\pm S D(n=3)$.

\section{In vivo anti-inflammatory activity carrageenan-induced paw edema}

Carrageenan-induced rat paw edema is a widely used to evaluate anti-inflammatory activity and constitutes a simple and regular animal model without any injury to the paw of animal. Animal paw edema used to investigate new anti-inflammatory drugs along with mechanisms involved in inflammatory process (Udavant et al., 2012). As a carrageenan- induced rat paw edema shows biphasic mechanism in which mediators activate in sequence to induce the inflammation. Histamine, bradykinin and serotonin are the mediators induce inflammation in the early phase. Prostaglandins (PGs) are detectable in the later phase of inflammation and PGs increase vascular permeability (Huang et al., 2011; Pinheiro et al., 2013).

The anti-inflammatory activity of petroleum ether, chloroform, methanol extract of I. coccinea and diclofenac sodium against paw edema induced by carrageenan (Figure 2).
Chloroform extract showed significant reduction of inflammation in carrageenan induced rat paw edema $(\mathrm{p}<0.05)$. The chloroform extracts of $I$. coccinea at the doses of $100 \mathrm{mg} / \mathrm{kg}$ moderately inhibited rat paw edema $28.42,36.07$ and $38.36 \%$ at $1 \mathrm{~h}, 2 \mathrm{~h}$ and $3 \mathrm{~h}$. respectively. Result revels that chloroform extract may inhibit production of histamine, serotonin and bradykinin in starting phase (Figure 2A) and also inhibit PGs in later phase (Figure 2B).

A
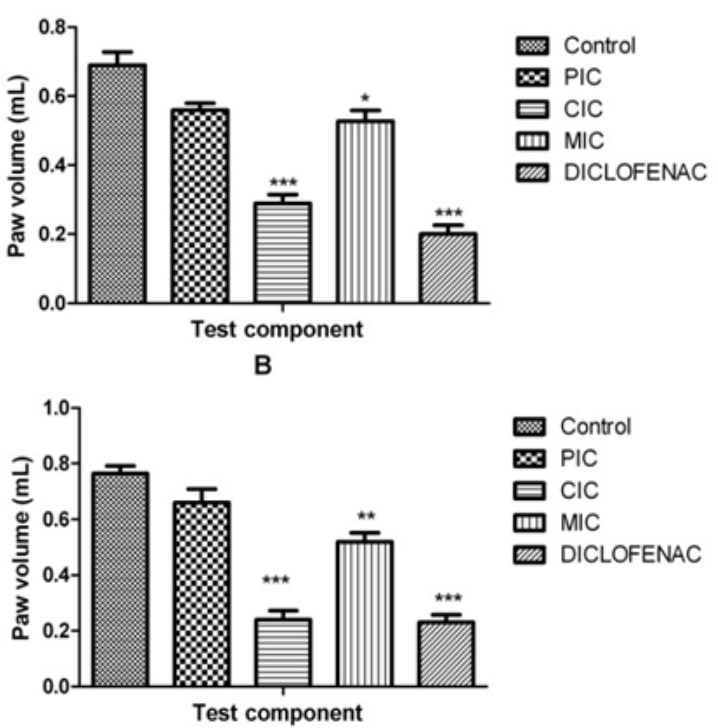

Figure 2. The effect of the oral administration of the crude extracts (PIC-Petroleum ether extract, CIC- Chloroform extract and MIC methanol extracts of Ixora coccinea) In early phase of carrageenan-induced paw edema (A) and in late phase of carrageenan-induced paw edema in rats(B). Each column represents the mean \pm standard errors of the mean. $* \mathrm{P}<0.05, * * \mathrm{P}<0.01$ and $* * \mathrm{P}<0.001$ represent significant differences compared to the control group. The statistical analysis was performed two-way ANOVA followed by Bonferroni's test.

\section{Antioxidant activity}

\section{Nitric Oxide Radical Scavenging Assay}

Nitric oxide (NO) is an important pleiotropic mediator produced by endothelial cells, macrophages, neurons, etc. $\mathrm{NO}$ is involved in regulation of many physiological processes like vasodilatation, smooth muscle 


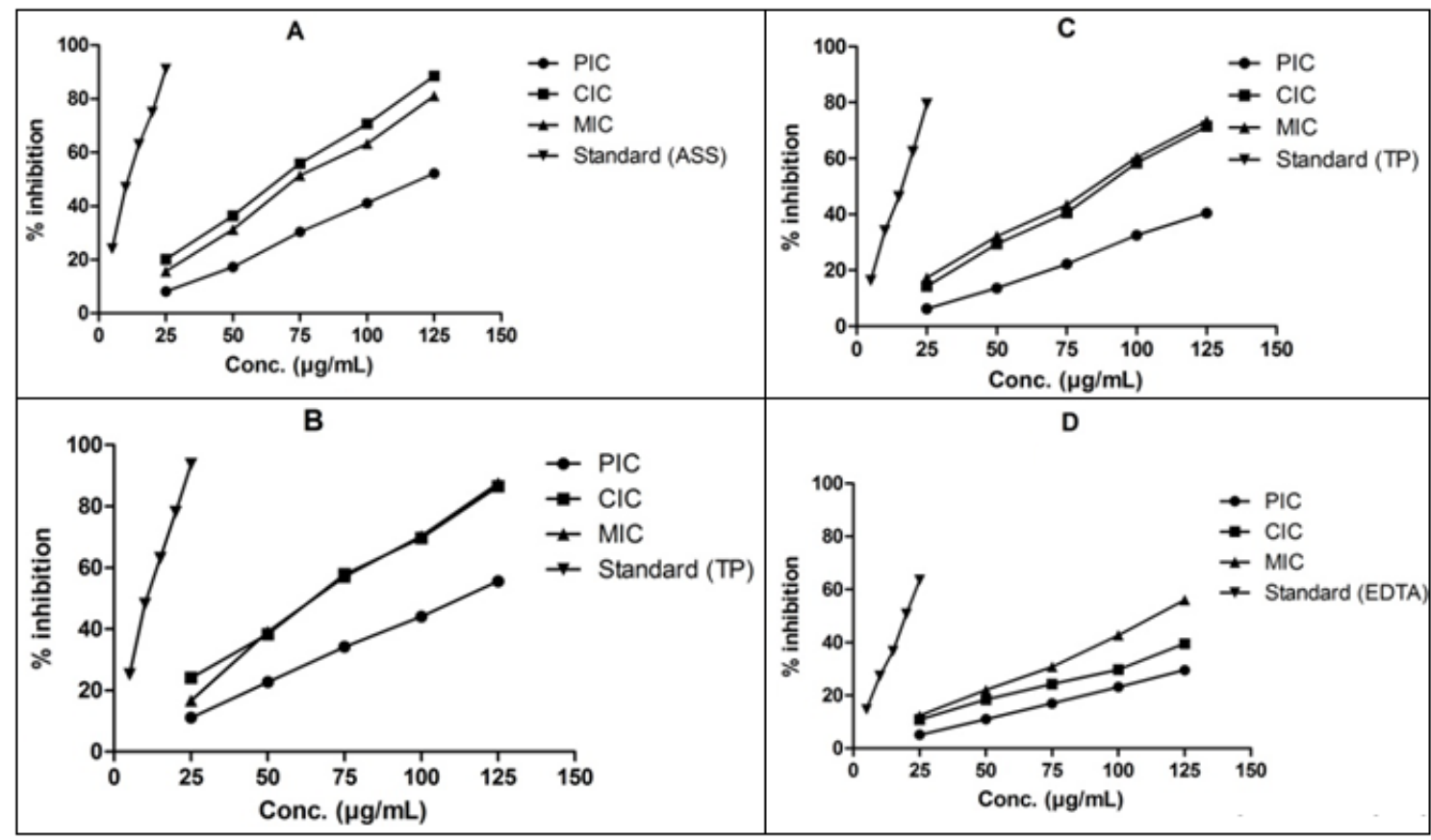

Figure 3. Antioxidant activity of Ixora coccinea extracts at different concentrations. Each value represents mean $(n=3)$. A=Nitric oxide free radical scavenging activity, $B=$ Hydrogen peroxide scavenging activity, $\mathrm{C}=\mathrm{DPPH}$ free radical scavenging and $\mathrm{D}=$ Ferrous ion chelating activity

relaxation, neuronal messenger, inhibition of platelet aggregation and regulation of cell mediated toxicity. (Hagerman et al., 1998). Nitric oxide scavengers have been shown to have good effects in some phases of inflammation and also in tissue damage observe in inflammation (Kelml et al., 2000).

Petroleum ether, chloroform, methanol extracts of $I$. coccinea stem and ascorbic acid were found to be scavenger of nitric oxide free radical with an $\mathrm{IC}_{50} 125.95 \mu \mathrm{g} / \mathrm{mL}, 69.06 \mu \mathrm{g} / \mathrm{mL}$, $77.28 \mu \mathrm{g} / \mathrm{mL}$ and $12.88 \mu \mathrm{g} / \mathrm{mL}$ respectively (Figure 3a).

\section{Hydrogen peroxide scavenging activity}

$\mathrm{H}_{2} \mathrm{O}_{2}$ radical scavenging activity is a useful method for assessing the antioxidant properties of samples. $\mathrm{H}_{2} \mathrm{O}_{2}$ is usually nonreactive to cells but may give rise to hydroxyl radicals, which is toxic to cell. Therefore removal of $\mathrm{H}_{2} \mathrm{O}_{2}$ is important and it can be carry by antioxidants that donate an electron to $\mathrm{H}_{2} \mathrm{O}_{2}$ and reduce in to $\mathrm{H}_{2} \mathrm{O}$, thus blocking the production of hydroxyl radicals and protecting from cell injury. The electron donation potential of a sample is directly proportional to its antioxidant potential (Verma et al., 2015).

Petroleum ether, chloroform, methanol extracts of $I$. coccinea stem and tocopherol were found to be scavenger of $\mathrm{H}_{2} \mathrm{O}_{2}$ with an $\mathrm{IC}_{50} 111.85 \mu \mathrm{g} / \mathrm{mL}, 67.84 \mu \mathrm{g} / \mathrm{mL}, 68.49 \mu \mathrm{g} / \mathrm{mL}$ and $11.58 \mu \mathrm{g} / \mathrm{mL}$ respectively (Figure $2 \mathrm{~b}$ ). Scavenging of $\mathrm{H}_{2} \mathrm{O}_{2}$ by extracts is due to their polyphenolics, which may donate electrons to $\mathrm{H}_{2} \mathrm{O}_{2}$. The extracts of $I$. coccinea might be used to provide a good $\mathrm{H}_{2} \mathrm{O}_{2}$ scavenger for humans.

\section{DPPH Free Radical Scavenging Assay}

DPPH is nitrogen centered free radical having an odd electron which gives a strong absorption at $517 \mathrm{~nm}$. DPPH purple color changes to yellow when its odd electron paired with the radical scavenger to form the reduced DPPH-H(Cai et al., 2003). The decrease in absorbance of DPPH free radical at $517 \mathrm{~nm}$ was due to radical scavenger by donating hydrogen (Dehpour et al., 2009). Various concentrations petroleum ether, chloroform, 
methanol extracts of $I$. coccinea and ascorbic acid were found to be good scavenger of $\mathrm{DPPH}$ radical with an $\mathrm{IC}_{50}$ of $162.87 \mu \mathrm{g} / \mathrm{mL}$, $87.72 \mu \mathrm{g} / \mathrm{mL}, 82.92 \mu \mathrm{g} / \mathrm{mL}$ and $16.07 \mu \mathrm{g} / \mathrm{mL}$, respectively (Figure 3c).

\section{Ferrous ion chelating activity}

Ferrous ion is one of the most effective pro-oxidants. In biological systems ferrous ion is interacting with hydrogen peroxide can lead to formation of very reactive hydroxyl radicals. Ferrozine forms complex with ferrous ions due to it is ferroin compound. The ferrozineferrous complex (magenta colored) formation is inhibited by chelating agent and intensity of magenta colour of complex is decrease. Thus, the chelating effect of the coexisting chelator can be determined by measuring the rate of color reduction(Sudan et al., 2014). The formation of the ferrozine- ferrous complex is inhibited by the $I$. coccinea extract, indicating ferrous chelating activity with concentration dependent manner (Figure 3d). I. coccinea extract as chelating agents that may forms bonds with a metal and act as effective secondary antioxidants because it may reduce the redox potential of metal, and thereby stabilize the oxidized form of metal ion. Petroleum ether, chloroform, methanol extracts of $I$. coccinea stem and EDTA were found to be ferrous chelating activity with an $\mathrm{IC}_{50}$ of $216.45 \mu \mathrm{g} / \mathrm{mL}, \quad 157.73 \mu \mathrm{g} / \mathrm{mL}, 114.68 \mu \mathrm{g} / \mathrm{mL}$ and $19.63 \mu \mathrm{g} / \mathrm{mL}$ respectively.

\section{CONCLUSIONS}

The chloroform and methanol extracts of $I$. coccinea stems showed anti-inflammatory and antioxidant activities supporting use in traditional medicine to treat in inflammatory condition. This study also affirmed that $I$. coccinea extracts is a potential source of antioxidant and could be used to prevent the diseases associated due to free radical. Due to antioxidant activity, extract might show antiinflammatory activity. However, future work is required for the isolation and characterization of the active constituents responsible for above activities.

\section{ACKNOWLEDGEMENT}

Volume 28 Issue 2 (2017)
Authors are thankful to BCUD, Savitribai Phule Pune University, Pune for providing Financial Grant. Authors are also thankful Principal, SMBT College of Pharmacy, Dhamngaon, India for providing necessary facilities.

\section{REFERENCES}

Hossain AM., Shah MD., 2015. A study on the total phenols content and antioxidant activity of essential oil and different solvent extracts of endemic plant $M$. borneensis. Arabian. J Chem, 8, 66-71.

Babu PN., Nagaraju B., 2014. Evaluation of antiulcer and In-vitro antioxidant activities of Ixora coccinea flowers and polyherbal extract in wistar albino rats. Int. J Pharm. Sci, 6, 239-344.

Basu BD, Kirtikar KR., Blatter E., 1999. Indian medicinal plants, 3(6) ed. Shri Satguru Publication, New Delhi.

Cai Y., Sun M., Corke H., 2003. Antioxidant Activity of Betalains from Plants of the Amaranthaceae. Journal of Agricultural and Food Chemistry, 51, 2288-2294.

Dehpour AA., Ebrahimzadeh MA., Seyed Fazel N., Seyed Mohammad N., 2009. Antioxidant activity of the methanol extract of Ferula assafoetida and its essential oil composition. Grasasy Aceites, 60, 405-412.

Dinis TCP., Madeira VMC, \& Almeida LM., 1994. Action of Phenolic Derivatives (Acetaminophen, Salicylate, and 5Aminosalicylate) as Inhibitors of Membrane Lipid Peroxidation and as Peroxyl Radical Scavengers. Archives of Biochemistry and Biophysics, 315, 161-169.

Ferguson LR., 2010. Chronic inflammation and mutagenesis. Mutation Research Fundamental and Molecular Mechanisms of Mutagenesis, 690, 3-11.

Ferreira LC., Grabe-Guimarães A., De Paula CA., Michel MCP., Guimarães RG., Rezende SA., De Souza Filho JD., Saúde-Guimarães DA., 2013. Antiinflammatory and antinociceptive activities of Campomanesia adamantium. J Ethnopharmacology, 145, 100-108.

Gülçin I., Elmastaş M., Aboul-Enein HY., 2012. Antioxidant activity of clove oil A powerful antioxidant source. Arabian. 
Journal of Chemistry, 5, 489-499.

Hagerman AE., Riedl KM., Jones GA., Sovik KN., Ritchard NT., Hartzfeld PW., Riechel TL., 1998. High Molecular Weight Plant Polyphenolics (Tannins) as Biological Antioxidants. J Agri. Food Chem, 46, 1887-1892.

Halliwell B., 2006. Oxidative stress and neurodegeneration: Where are we now? J Neurochemistry, 97, 1634-1658.

Huang MH., Bor Sen Chiu CS., Amagaya S., Hsieh WT., Huang SS., Shie PH., Huang GJ., 2011. Antioxidant, antinociceptive, and anti-inflammatory activities of Xanthii Fructus extract. J Ethnopharmacology, 135, 545-552.

Ikram A., Versiani MA., Shamshad S., Ahmed SK., Tahir Ali S., Faizi S., 2013. Ixorene, a new dammarane triterpene from the leaves of Ixora coccinea linn. Records of Natural Products, 7, 302-306.

Kasote DM., Katyare SS., Hegde MV., Bae H.,2015., Significance of Antioxidant Potential of Plants and its Relevance to Therapeutic Applications. Int. J. Bio Scie, 11, 982-991.

Kelm MA., Nair MG., Strasburg GM., Dewitt DL., 2000. Antioxidant and cyclooxygenase inhibitory phenolic compounds from Ocimum sanctum Linn. Phytomedicine 7, 7-13.

Khouya T., Ramchoun M., Hmidani A., Amrani S., Harnafi H., Benlyas M., Zegzouti Y.F., Alem C., 2015. Antiinflammatory, anticoagulant and antioxidant effects of aqueous extracts from Moroccan thyme varieties. Asian Pacific Jo Trop Biomed, 5, 636-644.

Kumar V., Bhat Z., Kumar D., Bohra P., Sheela S., 2011. In-vitro anti-inflammatory activity of leaf extracts of Basella alba linn. Var. alba. Int. Int J Drug DevRes 3, 176-179.

Kumaran A., Joel Karunakaran R., 2007. In vitro antioxidant activities of methanol extracts of five Phyllanthus species from India. LWT - Food Science and Technology, 40, 344-352.

Kumbhare MR., Sivakumar T., Udavant PB., Dhake AS., Surana AR., 2012. In vitro Antioxidant Activity, Phytochemical
Screening, Cytotoxicity and Total Phenolic Content in Extracts of Caesalpinia pulcherrima (Caesalpiniaceae) Pods. Pakistan Journal of Biological Sciences, 15, 325-332.

Madhavi P., Rao M., Vakati K., Rahman H., Eswaraiah MC., 2012. Evaluation of Anti-Inflammatory Activity of Citrullus lanatus Seed Oil by In-vivo and In-vitro Models. International Research Journal of Pharmaceutical Applied Science, 2, 104-108.

Maniyar Y., Bhixavatimath P., 2011. Evaluation of the hypoglycaemic and hypolipidaemic activities of the aqueous extract of the leaves of Ixora coccinea Linn in diabetic rats. Journal of Clinical and Diagnostic Research, 5, 1381-1384.

Martínez-Vázquez M., Estrada-Reyes R., Araujo Escalona A.G., Ledesma Velázquez I., Martínez-Mota L., Moreno J., Heinze G., 2012. Antidepressant-like effects of an alkaloid extract of the aerial parts of Annona cherimolia in mice. Journal of Ethnopharmacology, 139, 164-170.

Mhaskar K.S., Blatter E., Cus J.F., 2000. Kirtikar and Basu illustrated Indian Medicinal Plants, 3rd ed. Shri Satguru Publication, New Delhi.

Missebukpo A., Metowogo K., Agbonon A., Eklu-Gadeg K., Aklikokou K., Gbeassor M., 2011. Evaluation of Anti-asthmatic Activities of Ixora coccinea Linn (Rubiaceae). Journal of Pharmacology and Toxicology, 6, 559-570.

Momin F., Shikalgar T., Naikwade N., Kalai B., 2012. Cardioprotective effect of methanolic extract of Ixora coccinea Linn. leaves on doxorubicin-induced cardiac toxicity in rats. Indian Joumal of Pharmacology, 44, 178.

Muke SA., Aher AN., Pal SC., 2013. Analgesic and Anti-inflammatory activities of Ixora coccinea flower. Indian Drugs, 50, 64-66.

Nagaharika Y., Kalyani V., Rasheed S., Ramados S., 2013. Anti-inflammatory activity of leaves of Jatropha gossypifolia L. by HRBC membrane stabilization method. Journal of Acute Disease, 2, 156158.

Nagulsamy P., Ponnusamy R., Thangaraj P., 2015. Evaluation of antioxidant, anti- 
inflammatory, and antiulcer properties of Vaccinium leschenaultii Wight: A therapeutic supplement. $J$ Food and Drug Analysis, 23, 376-386.

Nwaehujor C.O., Ezeja M.I., Udeh N.E., Okoye D.N., \& Udegbunam R.I.2014. Anti-inflammatory and anti-oxidant activities of Mallotus oppositifolius (Geisel) methanol leaf extracts. Arab J Chem, 7, 805-810.

Peschel W., Snchez-Rabaneda F., Diekmann W., Plescher A., Lamuela-Ravents R., Buxaderas S. \& Codina C.2006. An industrial approach in the search of natural antioxidants from vegetable and fruit wastes. Food Chemistry, 97, 137-150.

Pinheiro MMG., Fernandes SBO., Fingolo CE., Boylan F., Fernandes PD., 2013. Antiinflammatory activity of ethanol extract and fractions from Couroupita guianensis Aublet leaves. J Ethnopharmacology, 146, 324-330.

Ragasa CY., Tiu F., Rideout JA., 2004. New cycloartenol esters from Ixora coccinea. Natural product research, 18, 319-23.

Ratnasooriya WD., Deraniyagala SA., Galhena G., Liyanage SSP., Bathige SDNK., Jayakody JRAC., 2005. Antiinflammatory Activity of the Aqueous Leaf Extract of Ixora coccinea. Pharmaceutical biology, 43, 149-152.

Saha MR., Alam MA., Akter R., Jahangir R., 2008. In vitro free radical scavenging activity of Ixora coccinea L. Bangladesh Journal of Pharmacology, 3, 90-96.

Sosa S., Balick M.J., Arvigo R., Esposito R.G., Pizza C., Altinier G., \& Tubaro A.2002. Screening of the topical antiinflammatory activity of some Central American plants. J Ethnopharmacology, 81, 211-215.

Spanos GA., Wrolstad R.E., 1990. Influence of processing and storage on the phenolic composition of Thompson Seedless grape juice. Journal of Agricultural and Food Chemistry, 38, 1565-1571.

Sudan R., Bhagat M., Gupta S., Singh J., Koul A., 2014. Iron (FeII) Chelation, Ferric Reducing Antioxidant Power, and Immune Modulating Potential of Arisaema jacquemontii (Himalayan Cobra Lily). BioMed Research International, 2014, 1-7.

Surana AR, Aher AN., Pal SC., Deore.UV., 2012. Evaluation of anthelmintic activity of Ixora coccinea. International journal of pharmacy \& life sciences, 2, 813-814.

Surana AR., Aher AN., Pal SC., 2013. In vitro and in vivo antioxidant activity of Ixora coccinea. Journal of Medicinal plants Research, 7, 3071-3075.

Udavant PB., Satyanarayana SV., Upasani CD., 2012. Preliminary screening of Cuscuta reflexa stems for Anti inflammatory and cytotoxic activity. Asian Pacific Journal of Tropical Biomedicine, 2, S1303-S1307.

Verma K., Shrivastava D., Kumar G.,2015. Antioxidant activity and DNA damage inhibition in vitro by a methanolic extract of Carissa carandas (Apocynaceae) leaves. Journal of Taibah University for Science 9, 34 40.

Xiao J., Sun J., Yao L., Zhao Q., Wang L., Wang X., Yuan X., Zhao B., 2012. Physicochemical characteristics of ultrasonic extracted polysaccharides from Cordyceps cephalosporium mycelia. International Journal of Biological Macromolecules, 51, 64-69.

Yasmeen M., Prabhu B., Agashikar N. V., 2010. Evaluation of the antidiarrhoeal activity of the leaves of Ixora coccinea Linn. In rats. Journal of Ayurveda and intergrative Medicine, 1, 287-291. 